CALIFORNIA AGRICULTURAL EXPERIMENT STATION CIRCULAR 382

APRIL, 1948

\title{
SULFUR-HOUSE OPERATION
}

H. J. PHAFF and E. M. MRAK

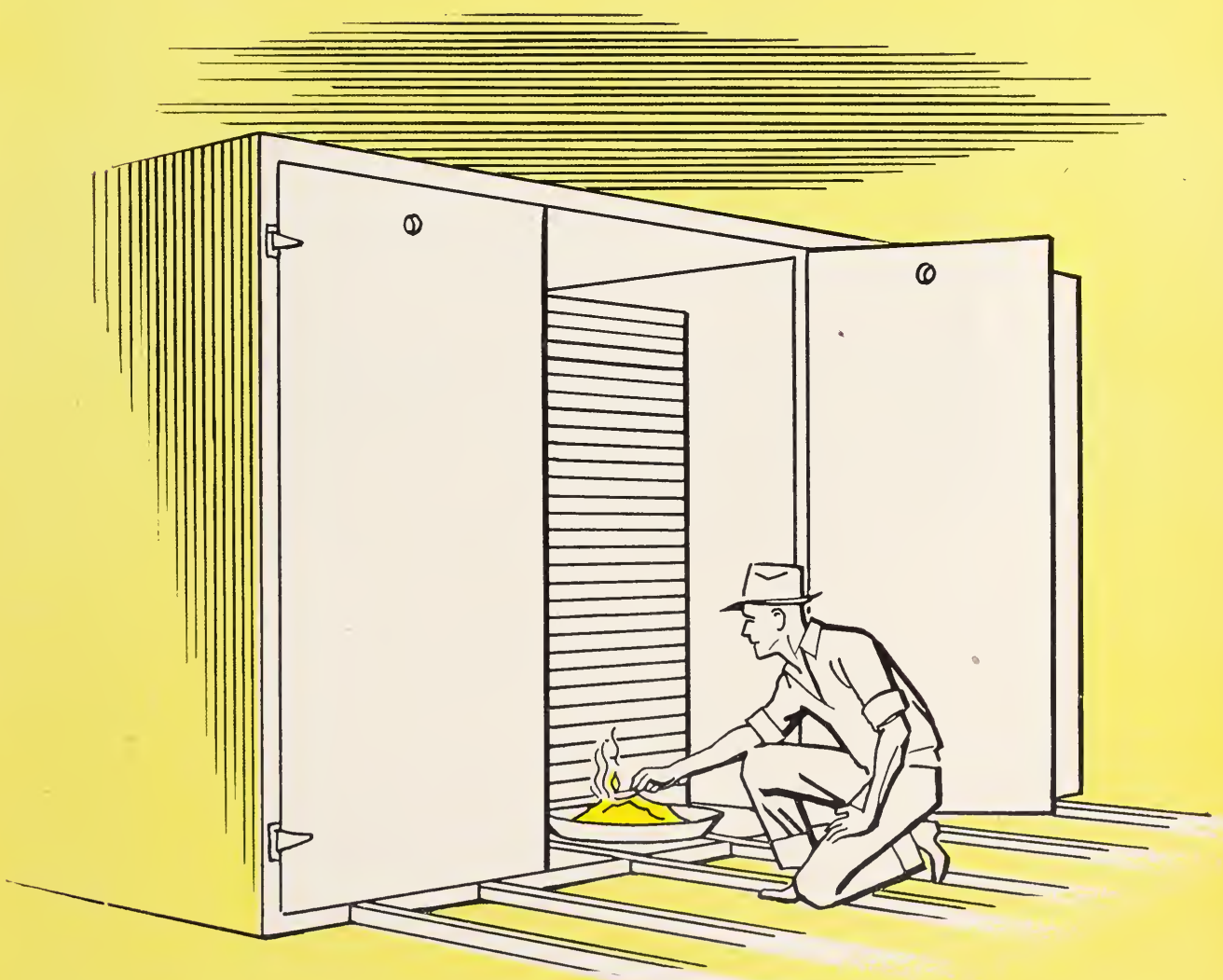

T H E C O L L E G E O F A G R I C U L T U R E UNIVERSITY OF CALIFORNIA - BERKELEY 
SULFURING IS A SIMPLE OPERATION, and most operators know the methods, but perhaps for this very reason the best results frequently are not obtained.

This circular is intended to give the fruit grower and small-scale operator a review in good sulfur-house operation. If your product is oversulfured or undersulfured, check your operations against the recommendations herein.

\section{Check}

Page

Is your sulfur house properly vented for good burning? 5

Is the sulfur burner in the right place? . . . . . . 6

Are you using a good quality of sulfur? . . . . . . . 7

Not using a make-shift burner, are you? . . . . . . . 8

What do you do with the match after lighting? . . . . . 8

Do you sulfur by guess, or by schedule? . . . . . . . 10

Many other hints and reminders are given in this circular. If you desire more complete or more technical reports on sulfuring methods, they may be obtained from your farm advisor.

THE AUTHORS: H. J. Phaff is Assistant Professor of Food Technology and Assistant Microbiologist in the Experiment Station.

E. M. Mrak is Associate Professor of Food Technology and Mycologist in the Experiment Station. 


\section{SULFUR-HOUSE OPERATION}

\section{H. J. PHAFF AND E. M. MRAK}

Fruits ARE SULFURED to aid in preserving their natural colors when sun-dried or dehydrated, and to retain certain food values both during processing and in storage later. Sulfuring also serves to prevent molding and fermentation, and is some protection against insects.

Sulfuring is accomplished by placing trayed fruit in a closed compartment and exposing it to the fumes of burning sulfur. When sulfur is burned it releases sulfur dioxide $\left(\mathrm{SO}_{2}\right)$, which is absorbed by the fruit.

The operation of a sulfur house is quite simple. The methods are generally well known. Perhaps for this reason, sulfur houses are often not used to best advantage. Many experienced operators do not completely understand the principles which are involved. Other operators have carried out the operation so often that they have lost sight of the fact that each detail of the relatively simple process is, in itself, highly important to the full and proper sulfuring of fruit.

For instance, the instructions may call for 5 pounds of clean sulfur to be burned for 4 or 5 hours. "Clean" sulfur means a product that is absolutely free of any foreign substance. If any material other than sulfur is present, only a portion of the sulfur will burn, perhaps 80 per cent, perhaps as little as 10 per cent. It is hard to tell exactly how much has burned, merely by examining the burner afterwards. Some operators try to solve their problems by using sulfur liberally-more than is necessary-but if their burn is poor, they may double the amount of sulfur and still not have a long enough burn to properly sulfur their fruit.

Impure sulfur, a burner foul with slag, a leaky house, poor circulation inside the house, even a match carelessly dropped into the burner as it is lighted-any of these can cause improper sulfuring.

Even though you may be fully familiar with sulfur-house operation, it will pay you to check your methods carefully against the recommendations contained in this circular, to pay close attention to the smallest details of your operation.

\section{Planning the Sulfur House}

\section{Location of the House}

Sulfur houses should be placed close to both the cutting shed and dry yard or dehydrater, yet far enough away to prevent gas fumes from bothering workers. Do not place them where there is danger of damaging near-by fruit trees. In selecting the location, take advantage of prevailing winds which will carry the fumes away. Sulfur houses should not be built under the same roof with a dehydrater, because the moving air will distribute sulfur fumes all through the plant.

\section{Types of Houses}

Various types of sulfuring houses are used in California. Basic requirements are: (1) a design to promote rapid, uniform circulation of sulfur fumes; (2) economical construction; (3) durability under the severe usage the house receives. Smaller operators generally prefer the one-car house as being more convenient. This is constructed to contain one stack of about 25 trays of fruit on a wheeled flatcar, which is run into the house on steel rails. Larger operators find economy 
in construction of multiple-car houses, but as a precaution against fire usually build them as two or more separate structures, rather than as one continuous building. Two examples of sulfur houses are shown in figure 1.

The lift-over or hood-type sulfuring equipment, which can be placed over trays stacked on cars or on wooden horses, is sometimes used in very small operations or to supplement regular equipment when a crop is unusually large (fig. 2).

Built of paper or panel board, on light wood frame, this type is not long-lived, and is inconvenient to operate.

Plans and specifications for building sulfur houses of good design may be obtained from the Agricultural Extension Service, University of California, Berkeley 4. One type, listed as plan C-173, is for a gable-roofed three-compartment
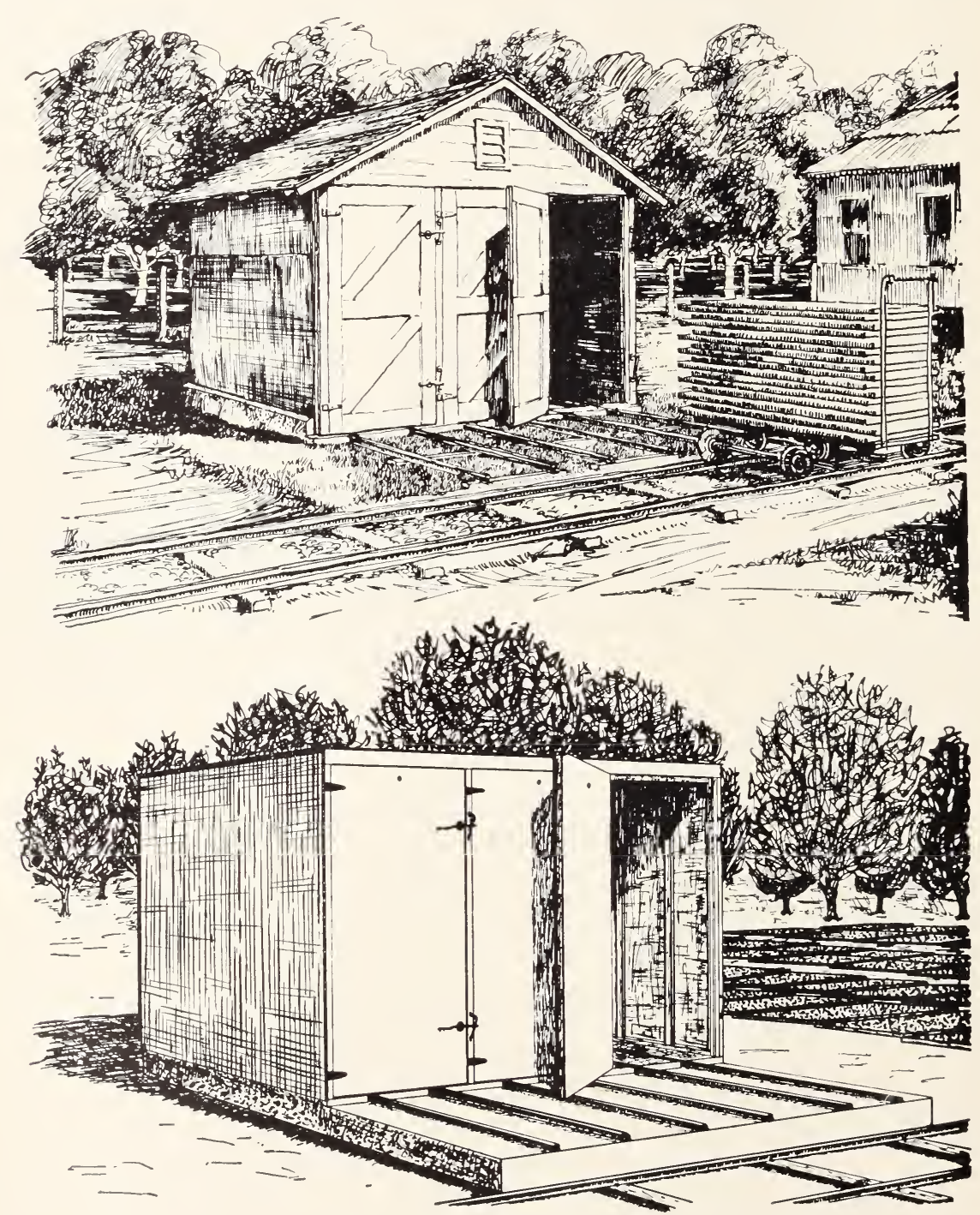

Fig. 1. Sulfur houses of good design. The upper picture shows a gable-roofed threecompartment house; the lower is a three-compartment, flat-roofed plywood structure. Your county farm advisor can tell you how to get plans for these. 
house; another, listed as plan C-194, is for a flat-roofed three-compartment house. One unit of either of these plans may be constructed, to hold a single car. Information concerning the plans may be had from your county farm advisor.

The compartment of any sulfur-house should be longer than the tray stack in order to permit placing the burner on the floor between the car of fruit and the door and to secure the best distribution of sulfur dioxide $\left(\mathrm{SO}_{2}\right)$ (fig. 3 ).

Placing the burner as suggested will eliminate a fire hazard. Burning sulfur generates a considerable amount of heat. IV here the compartment is short and the burner must be set in a pit under the end of the tray stack, a metal baffle sheet should be fastened under the end of the car for fire protection. Loose baffles laid over the burner are likely to reduce the burning rate of the sulfur.

If the sulfur house holds more than two single cars, or more than one double car of fruit, it is better to burn sulfur at both ends of the house. In this case it is best to allow space at the back to keep the burning sulfur well away from the trays. Where this arrangement is made, it is convenient to have a small rear doorabout $2 \times 3$ feet - for filling and lighting the rear burner.

\section{Providing Circulation}

A sulfur house should be relatively tight against air leakage. If light leaks are visible to anyone standing in a closed sulfur house for 2 or 3 minutes, the house is certainly not tight. In a really tight house the air present is insufficient to burn the required amount of sulfur. Vents are necessary to provide the fresh air for proper burning. An extinguished fire and incompletely burned sulfur wastes the sulfur and undersulfurs the fruit.

When sulfur has failed to burn, the color of the remaining slag shows why. Light-colored slag means the house was too tight; black-surfaced slag points to impurities in the sulfur (fig. 4).

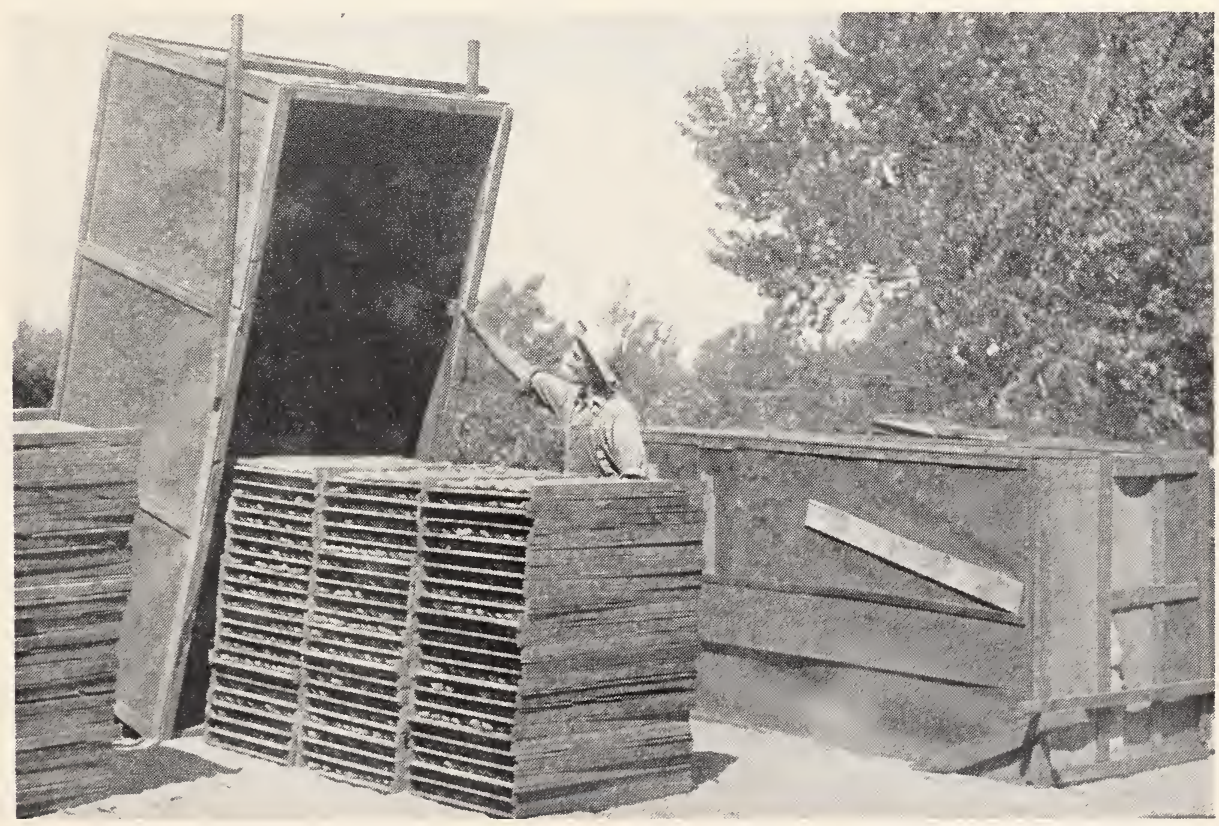

Fig. 2. The hood-type sulfuring equipment, shown above, may be lifted over stacks of trays. It is of temporary construction, but may be used in a small operation, or to supplement other equipment. 


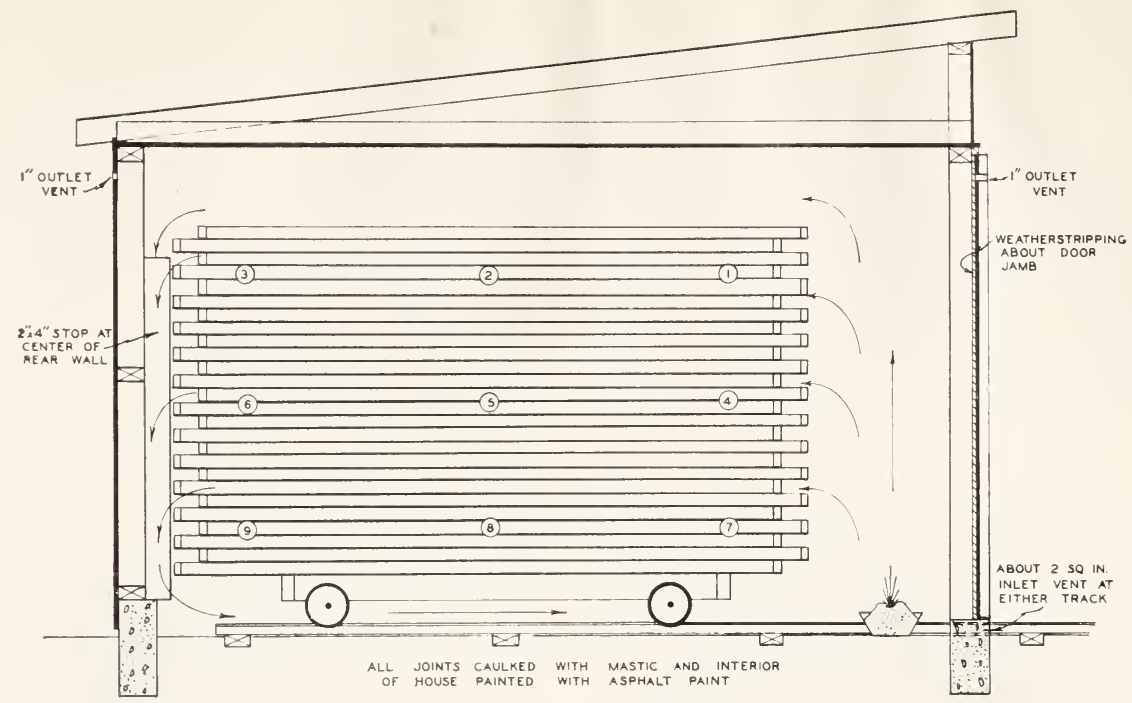

Fig. 3. Longitudinal section of sulfur house, showing a car loaded with field trays and the location of the sulfur burner and ventilation openings. Convection currents aid in equalizing the gas distribution; the arrows indicate the direction of the fumes flow as determined by measurements made at the points designated by numbers. Note the stop at the center of the rear wall, to hold stack of trays away from the wall and allow full gas distribution.

The simplest system in air-venting the house is to make an inlet hole of not more than $1 \times 2$ inches beside each rail at the base of the sulfur-house door, and one outlet hole of 1 -inch diameter at the top center of both the rear wall and the door. (See fig. 3.) This will give the correct venting for a tight one- or two-car house if one 10-inch-diameter pan is used. The outlet vents should be increased if the size or number of burners is increased; and there should be two additional inlet vents in the rear of the house if two burners are used. The vents needed for tight houses for the sizes of burners commonly used are shown in the following table:

Size and number of burners

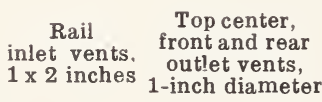
10- or 11-inch burners :

$\begin{array}{ccc}1 \text { burner....... } & 2 & 2 \\ 2 \text { burners....... } & 4 & 4 \\ 2 \text {-inch burners : } & & \\ 1 \text { burner........ } & 2 & 3 \\ 2 \text { burners...... } & 4 & 5\end{array}$

Figure 3 shows arrows which indicate the distribution of sulfur dioxide gas from the burning sulfur. To insure free circulation of gas around the trays, a $2 \times 4$-inch stop should be placed to keep the end of the tray stack away from the rear wall of the sulfur house.

If field trays are used, they must be stagger-stacked on the car to permit complete circulation of the sulfur dioxide in the sulfur house, as shown in figure 3. When open-side dehydrater trays are used, this is not necessary.

\section{Constructing the House}

Economy of construction and durability are two important features of any sulfur house. Whatever construction material is chosen, the compartment must be tight against air leakage. It should be so tight that a person inside the closed compartment cannot see any light sources other than the air-supply vents previously described. During the sulfuring, fumes should be seen escaping from these vents only. Using extra sulfur to compensate for leakage should be avoided; it is wasteful and prohibits uniform sulfuring. 
There are several types of doors which may be used. Closely fitted, weatherstripped, side-hung doors are recommended, because there is less chance they will warp and cause leakage. Vertically sliding doors, which may be hard to handle, and swinging top-hinged doors with counterbalances, though not so tight, are both used. Whatever the door chosen, it should be well braced to prevent warping. There should also be protection around doors to keep water from coming into the house.

Some operators complain that concrete sulfur houses deteriorate from the action of the sulfur. To prevent this, use a rich mix-lots of cement, not so much sand and gravel; then, after the cement is completely dry, thoroughly coat the interior with asphalt paint.

\section{Remodeling Old House}

It is usually poor economy to remodel old sulfur houses unless the framework is sound. Structures on mud sills should be raised and a continuous concrete floor and foundation slab put in to keep the house rigid and tight and to hold the tracks in position.

In remodeling, you should calk with asphahtic mastic (a pliable waterproof filler procurable at lumber dealers) all cracks and structural joints in walls and ceiling, especially at the sill and plate. Then apply two coats of asphalt paint to seal the structure. Close all visible leaks other than vents. If you cannot seal the interior, reline with plywood and seal all joints with mastic or asphalt-impregnated felt or building paper.

\section{Sulfur and Sulfur Burners}

\section{Quality of the Sulfur}

It is cheaper in the long run to use high-quality, clean sulfur rather than the poorer grades. Good sulfur, burned in a properly constructed house, will consume from 95 to 100 per cent of its weight in burning. When the burn is complete, there will be little residue in the pan. Poorér sulfur will leave a high percentage of dark slag (residue). When there is a clean, yellow slag left in the burner, it indicates that there is an insufficient supply of fresh air in the house to keep the sulfur burning-not a poor grade of sulfur (fig. $4, A$ ).
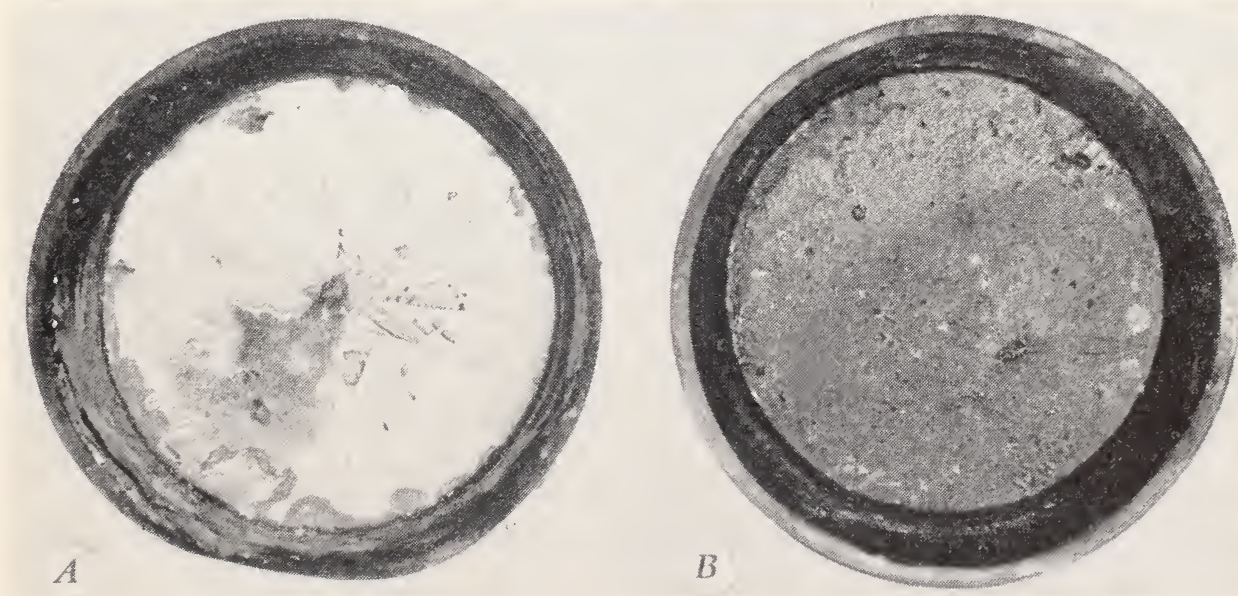

Fig. 4. Slag left after incomplete burning: A, light-colored slag shows that the fire was smothered by lack of fresh air; $\boldsymbol{B}$, dark-surfaced slag shows that the fire was smothered by carbon or other impurities which floated to the surface of the burning sulfur. 
When recommended sulfuring times are followed, the sulfur should be completely burned when the sulfur house is finally opened. In fact, most recommended sulfuring times call for the fruit to remain in the house well after the burn is complete in order that all the remaining sulfur dioxide may be absorbed. Seven pounds of sulfur will burn out in 3 hours, under normal conditions, in a 10 to 12 -inch-diameter pan burner.

When sulfur is lighted, it melts almost immediately; the liquid finds its level at the bottom of the container and burns on the top until it is gradually consumed.

When impurities are present-small amoumts of straw, matches, paper, oil, sacking material-this material is burned first, leaving a residue of ash. This residue floats to the top and smothers the burning sulfur, leaving slag which is black over most of its surface (fig. 4, B).

When you buy, get pure sulfur. Store it carefully, keep it dry and clean and away from oil, which contaminates it very readily. Even the fumes of kerosene will enter stored sulfur and help to destroy its efficiency by decreasing the amount which will burn.

\section{Types of Burners}

Clean containers, such as tin pans 10 to 12 inches in diameter and 3 to 5 inches deep, or metal water buckets 10 to 12 inches in diameter, are used as sulfur burners. For fruits such as pears, which require long periods of sulfuring, buckets are most satisfactory. Those made of black iron are more durable than regular buckets. All burners should be carefully examined for leaks because the molten sulfur can be lost through small holes.

It is imperative to keep all burners clean. Never use old smudge pots or oily, dirty containers unless they have been thoroughly cleaned first. When you purchase new containers, be sure to wash them carefully with soap and water to remove any oily coating.
Clean all burners several times during the season to get rid of adhering powder, black material, and slag.

Earthen pits should never be used, because much of the sulfur will not burn.

Shallow, concrele hearths are satisfactory if their construction makes them easy to clean.

\section{Lighring the Sulfur}

Light the sulfur in the burner by touching it in a few spots with a lighted match. Then discard the match.

Do not use materials such as straw, burlap, newspaper, or excelsior, to light the sulfur. These materials form a carbonaceous layer on the melted sulfur and smother the flame.

Close the sulfur house tightly when the sulfur begins to burn.

Burning may be too rapid if burners have unusually large surface areas. Fast burning may deposit particles of unburned sulfur on the fruit. If a strong wind is blowing directly against either the front or rear wall of the sulfur house, close the outlet on the windward side to reduce drafts in the house. If the wind is blowing against the front of the house, partly close air inlets.

Installation of forced-draft sulfuring is expensive. This type of operation requires more supervision than the ordinary method of sulfur dioxide distribution (shown in fig. 3), and if not properly conducted will not justify the additional cost. Forced draft may carry unburned sulfur particles to the fruit, or may force the gas out of the sulfur house before it can be absorbed by the fruit. However. large plants using the forced-draft system find it possible thus to use a cheaper grade of sulfur.

\section{Sulfur Dioxide Absorption}

Sulfur dioxide absorption by fruits depends on the variety of the fruit. its maturity (sugar content). the length of time it is in the sulfur house, the quality 
and amount of sulfur burned, temperature within the house, and the house construction.

A low sulfur dioxide content in the finished product, either sun-dried or dehydrated, may be due to faulty sulfuring methods or poor drying conditions, or to a combination of both factors.

Ripe fruit absorbs sulfur dioxide more slowly than green fruit, but holds it much better during and after drying. Unripe fruit loses sulfur dioxide very quickly during and after drying.

Blanched fruits to be dehydrated may be sulfured about one-third shorter time than unblanched fruits to be sun-dried, because sulfur dioxide is retained much better during dehydration than during sun-drying. The same is true with unblanched fruit to be dehydrated, but to a lesser degree.

Fruit can be oversulfured. When oversulfuring is extreme, ripe apricots and freestone peaches will break down, lose their form, and bleed excessively.

There is no simple way to tell when fruit is properly sulfured. If you follow the directions in the circular-carefully and in all respects-your sulfuring will be adequate. If your dried product is unsatisfactory, check your sulfuring and dehydration methods. Operators who deal with packers can often have sulfur analyses run-1,500 to 2,500 parts per million is the proper range.

\section{Sulfur Dioxide Retention}

Retention of sulfur dioxide in fruits depends largely on the drying method and type of fruit. In general, the faster the fruit is dried, the better the retention. High humidity causes sulfur-dioxide losses from drying fruit and stored dried fruit.

Sulfur dioxide retention during sundrying is always less than when fruit is dehydrated because sun-drying is a much slower process. Where sun-drying is used, climatic differences of the various districts, particularly the temperature and relative humidity, naturally affect the retention.

For example, fruit dried in the Aromas district retains little sulfur dioxide because the humidity is high, the air is cool and the drying time may be as long as two or three weeks. In the Hemet area in Riverside County, on the other hand, the air temperature is high, the humidity low, and the drying time only two or three days.

In order to obtain good retention in

\section{TABLE 1}

\section{COMPARISON OF THE EFFECT OF SUN-DRYING AND DEHYDRATION ON THE RETENTION OF SULFUR DIOXIDE BY APRICOTS}

\begin{tabular}{|c|c|c|}
\hline Treatment under typical farm conditions & $\begin{array}{l}\mathrm{SO}_{2} \text { retention } \\
\text { p.p.m. }\end{array}$ & $\begin{array}{l}\text { Per cent increase } \\
\text { in } \mathrm{SO}_{2} \text { retention } \\
\text { of dehydrated } \\
\text { over sun-dried }\end{array}$ \\
\hline \multicolumn{3}{|l|}{ Test 1: } \\
\hline Freshly sulfured fruit. . . . . . . . . . . . . & 1,418 & $\ldots$ \\
\hline Completely sun-dried . . . . . . . . . . . . & 370 & $\ldots$ \\
\hline Completely dehydrated $\ldots \ldots \ldots \ldots \ldots \ldots \ldots$ & 778 & 110 \\
\hline \multicolumn{3}{|l|}{ Test 2: } \\
\hline Freshly sulfured fruit. . . . . . . . . . . & 1,820 & \\
\hline Completely sun-dried $\ldots \ldots \ldots \ldots \ldots \ldots \ldots$ & 690 & $\ldots$ \\
\hline Sun-dried 24 hours to fix color, ${ }^{*}$ then dehydrated . . . . . . . & 1,190 & 72 \\
\hline
\end{tabular}

* Fruit may be blanched instead of exposed to sun to fix color, and equally good sulfur dioxide retention will result during dehydration. 
areas where the climate is cool and humid, the fruit should be placed on the drying field in the sun immediately after sulfuring. It is best to spread the fruit during the day. When it is necessary to sulfur at night in humid areas it is best to light the sulfur after midnight. Fruit permitted to stand in the sulfur house all night may bleed badly.

The drying field should be located so the drying fruit will be exposed to a mod- erate breeze. Trays should not be placed on green grass, near streams, near alfalfa fields, nor in areas protected from moving air. Sulfur dioxide retention is always much better when fruit is dried in a dehydrater (see table 1). For this reason drying by dehydration is recommended for areas such as Aromas.

Immature fruit does not retain sulfur dioxide well even when it is dehydrated. Select only mature fruit for sulfuring.

\section{Schedules for Sulfuring Fruit}

Table 2 suggests approximate sulfuring time and the amounts of sulfur to be burned, using one burner approximately 10 inches in diameter and a tightly constructed, well-vented sulfur house.

The hours of sulfuring and quantity of sulfur burned will naturally vary with the size, maturity, and variety of the fruit and with the location of fruit production and drying. They will also vary with the temperature in the sulfuring house at the time of sulfuring.

TABLE 2

RECOMMENDED SULFURING TIME AND AMOUNTS OF SULFUR

\begin{tabular}{|c|c|c|}
\hline \multicolumn{3}{|c|}{ For fruits to be sun-dried } \\
\hline Fruit & $\begin{array}{l}\text { Number of hours } \\
\text { sulfuring }\end{array}$ & $\begin{array}{l}\text { Pounds of sulfur } \\
\text { per single car }\end{array}$ \\
\hline Apricots . . . . . . & 4 to 5 & 4 to $4 \frac{1}{2}$ \\
\hline Freestone peaches. & 5 to 6 & 5 to $5 \frac{1}{2}$ \\
\hline Nectarines . . . . . . & 4 to 5 & 4 to $41 / 2$ \\
\hline \multirow[t]{2}{*}{ Pears....... } & 24 to 48 & 16 to 32 \\
\hline & & ( 8 pounds every 12 hours) \\
\hline
\end{tabular}

For fruits to be dehydrated

\begin{tabular}{|c|c|c|}
\hline Fruit & $\begin{array}{l}\text { Number of hours } \\
\text { sulfuring }\end{array}$ & $\begin{array}{l}\text { Pounds of sulfur } \\
\text { per single car }\end{array}$ \\
\hline 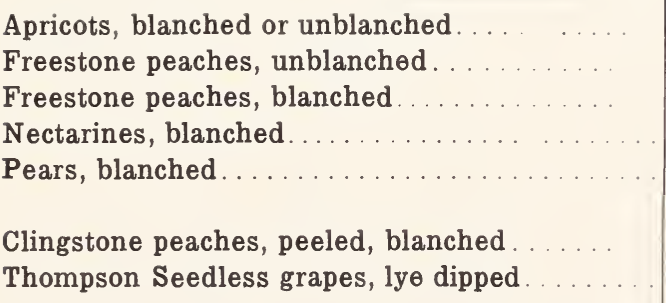 & $\begin{array}{l}3 \text { to } 3 \frac{1}{2} \\
4 \text { to } 5 \\
3 \text { to } 4 \\
4 \text { to } 5 \\
10 \\
3 \\
3 \text { to } 4\end{array}$ & 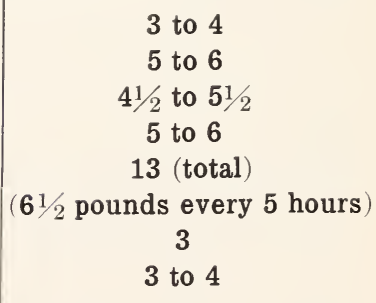 \\
\hline
\end{tabular}





\section{The PUBLICATIONS CATALOG}

is issued once a year. It lists the printed publications on farm subjects, which are available to all farmers without charge at the College of Agriculture.

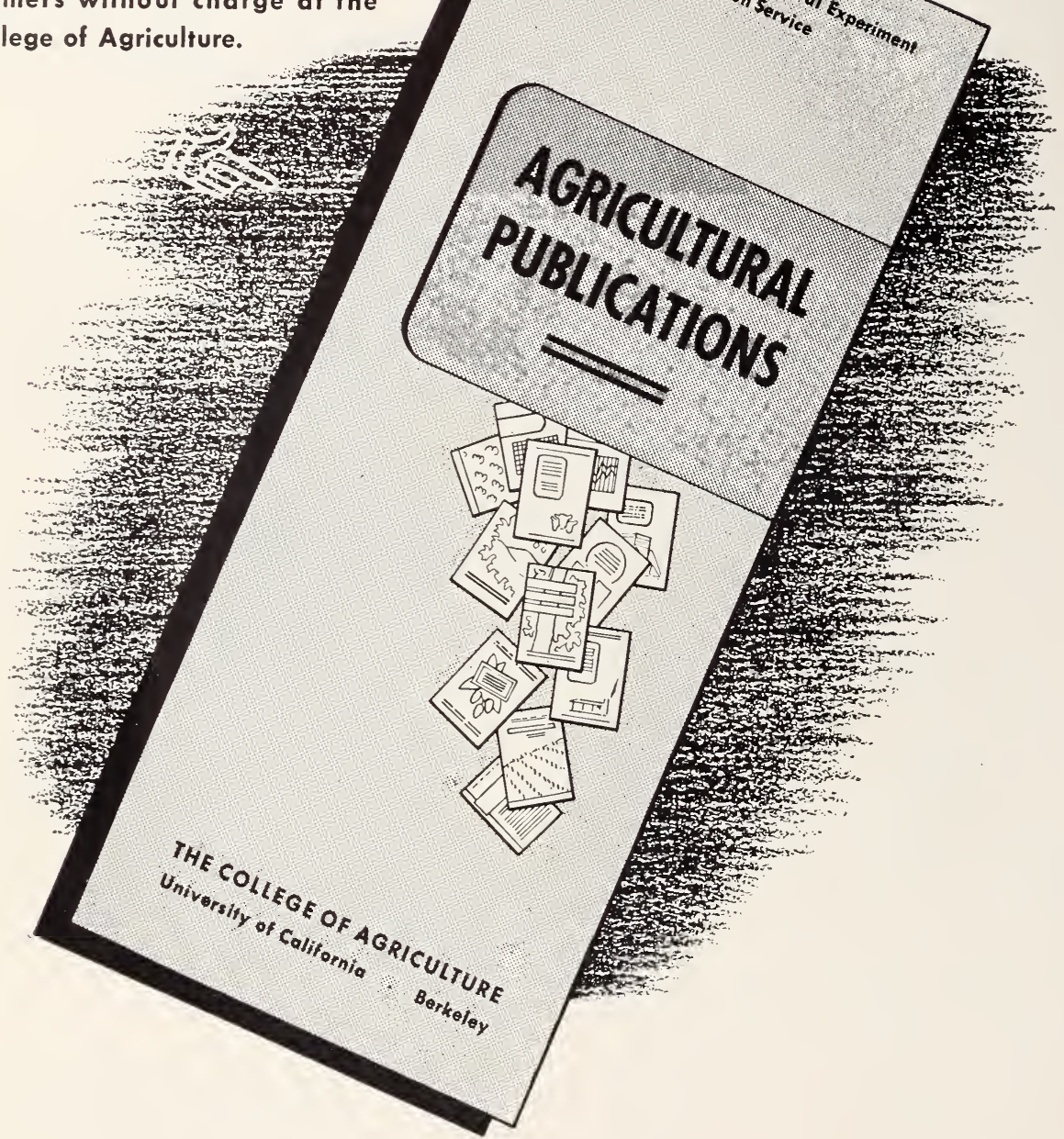

If you would like to be placed on the list to receive this catalog without charge, send your name and address to: 500

PUBLICATIONS OFFICE - COLLEGE OF AGRICULTURE UNIVERSITY OF CALIFORNIA • BERKELEY 4, CALIFORNIA 